\title{
Cross-Pollination of Freudian Psyche and Kantian Imperatives in Dubliners
}

\author{
Julie Prathibha Leo ${ }^{1}$ \\ ${ }^{1}$ Faculty of Language Studies, Arab Open University, Dammam, Saudi Arabia \\ Correspondence: Dr. Julie Prathibha Leo, Faculty of Language Studies, Arab Open University, Dammam, Saudi \\ Arabia. E-mail: j.leo@arabou.edu.sa
}

Received: August 4, 2021

Accepted: September 10, 2021

Online Published: September 19, 2021

doi:10.5539/ells.v11n4p17

URL: https://doi.org/10.5539/ells.v11n4p17

\begin{abstract}
The foundation of Dubliners of James Joyce was laid on the cross-pollination of Freudian and Kantian theories. Cross-pollination of Kantian imperatives and Freudian psyche is conspicuous in 'Eveline' and 'Painful case' in Dubliners, where lies the focal point of this analysis. Cross-pollination is highly obvious in the protagonists of two short stories 'Eveline' and 'Painful case'. Psychological and scientific analysis of the characters brought the embedded cross-pollination into the limelight. For Freud, humans exist as a composite of a natural, biological matrix (termed unconsciousness) and another part, the conscious ego (Tauber, 2009). Sigmund Freud's super-ego is the womb of guilt feeling, which functioned so well in the characters of Joyce. The explicit dilemma of Eveline and the implicit dilemma of Mr. Duffy have been analyzed through the lens of Kantian imperatives.
\end{abstract}

Keywords: James Joyce, Dubliners, cross-pollination, Freudian psyche, Kantian imperatives

Whether to do it or not, is an unavoidable or at times an inescapable phenomenon of all humans. At times we fall prey to situations and do what society wishes or taught us to do. It's either the desires that lead to choosing or it's the rule of conduct that one is forced to choose. Millions make decisions at every single moment and the time when Dubliners of James Joyce are left with no choice other than to decide even if they know that their choice is an entrance to suffering. Moral actions, can it be named or natural desire or inclination, Immanuel Kant brings them all under the roof of 'Categorical or Hypothetical imperatives'. Duty/responsibility/goodwill/morality is the driving force behind the choice of any adult. The satisfaction of others is the ultimate and source of self-delight. Sigmund Freud's model of psychic structure and function are closely parallel to Kant's in several respects. For Freud, humans exist as a composite of a natural, biological matrix (termed unconsciousness) and another part, the conscious ego (Tauber, 2009). Sigmund Freud's super-ego is the womb of guilt feeling, which functioned so well in the characters of Joyce. Cross-pollination refers to the fusion of genres, ideas, thoughts, philosophy, etc. either to enrich the literary work or the character sketch. Pollinating Freudian psychic structure and Kant's imperatives, Joyce created a perfect fusion. Cross-pollination of Kantian imperatives and Freudian psyche is conspicuous in 'Eveline' and 'Painful case' in 'Dubliners', where lies the focal point of this analysis. 'Eveline' and 'Painful Case' are only stories where Joyce has deliberately given a visual effect to the seeding of cross-pollination. The explicit dilemma of Eveline and the implicit dilemma of Mr. Duffy performatively given vent to severe criticism as they couldn't taste the fruit of happy union.

According to Immanuel Kant, if someone wants to get something, then he must work for it. For example, if one wants to earn his livelihood, then one must find a job. The commands that one should follow if he/she wants something is called hypothetical imperative. Hence, hypothetical imperatives are about prudence, rather than morality. Kant viewed morality not in terms of hypothetical imperatives, but through what he called categorical imperatives. Regardless of the desire, a person must follow morality, even if his choice led him to suffer.

Id, ego, and super-ego are the three parts of the psychic apparatus defined in Sigmund Freud's structural model of the psyche; they are the three theoretical constructs in terms of whose activity and interaction mental life is described. According to this model, the uncoordinated instinctual trends are the "id"; the organized realistic part of the psyche is the "ego", and the critical and moralizing function is the "super-ego" (Miller et al., 2009). Joyce has used Kantian imperatives and Freudian psyche to chisel his characters, Eveline and Duffy, perfectly.

James Joyce, a prominent Irish writer tried his hand in presenting the $20^{\text {th }}$-century Irish society through his 'Dubliners'. It was written when Ireland was suffocating due to the corrupt Catholic Church, British colonization, 
and Irish nationalism. James Joyce's, 'Dubliners' highlights the emotions, aggression, and suppression of Dubliners knotted with death, frustration, solitude, and barrenness. In the eyes of Joyce, people were paralyzed and the call for Joyce's moral duty made him mirror the Irish society through his fifteen tales in 'Dubliners'.

"My intention was to write a chapter of the moral history of my country, and I chose Dublin for the scene because that city seemed to be the centre of paralysis. I have tried to present it to the indifferent public under four of its aspects: childhood, adolescence, maturity, and public life. The stories are arranged in this order", says Joyce: Letter to Grant Richards, 5 May 1906 (Ellmann, 1967, p. 83).

All the 15 tales are searing analyses of his contemporary society that widens the psychoanalytical scope for the researchers. Dubliners' Freudian ground is highly obvious in his short stories in 'Dubliners'. It was a time of identity crisis when James Joyce penned these short stories. Each story is unique in picturizing the mind of the characters. The internal monologues in the stories make them intricate. The dilemmas and the conversation between the conscious minds, ego with the super-ego is pitched by Joyce indeliberately. A strong sense of the cross-pollination of Kant's philosophy and Freud's theory of mind is inevitable. The readers of 'Dubliners' are assigned the role of psychoanalysts, who pierce through the minds of Dubliners. Joyce was not more concerned about the actions and thoughts of the characters whereas he wished his fellow Dubliners peering the characters and understand themselves better. Freud did the same, as he placed the readers of his 'Wolf man' as psychoanalysts.

Joyce's short story 'Eveline' was the advent between adolescence and maturity (Kuparadze, 2012). Eveline is nineteen years old Irish girl living with her drunkard father, dreaming of a bright future with her sailor lover, Frank. She finds Frank to be the only option left before her to escape from loneliness and the domestic world. Since she became the carer of the family after the death of her mother, she is indecisive and oscillates between whether to be selfish or selfless. Eveline is left with only two options, either to elope with her boyfriend Frank or to take care of her father, brother, and the two young children to fulfill the promise she had given to her mother. Eveline continues to work on narcissistic perfection. Freud stresses that the ego-ideal resulted from a transformation of the belief in the possibility of perfection, a conviction that must be abandoned as the psyche matures. Eveline's immature psyche fails her by not looking at her future. Categorical imperatives give no room to the sense of guilt. In Freudian terms, Eros is highly absent in Eveline. Though Eveline reaches the dock, her ears turned deaf to the call of Frank and avoided the dramatic elopement. Eveline displays the psychoanalytical attitude of servitude, passivity, and the sense of being overwhelmed by masculine oppression (Ingersoll, 1993, p. 1). Eveline is paralyzed here by Joyce, through the story of, 'Eveline', raises for women's freedom and emancipation in the Irish society, where women like Eveline voluntarily turn down the chance that makes her own attempt futile. Looking through the lens of physiology, brain activities such as feelings and decision-making is controlled by the brain parts such as the insula, cingulate cortex, medial and lateral prefrontal cortex, superior temporal cortex, and superior parietal cortex (ArticlesPsychology, October 27, 2017). Dopamine, an organic chemical present in the neurons in the brain transmits the feeling of pleasure, and loss of dopamine-secreting neurons leads to motor impairment (Conrad, 2018). Biologically, Eveline's Lateral prefrontal cortex-Dopamine could be another factor for Eveline's choice of keeping away the joyful future.

Self-imposed isolation of Eveline neither brings happiness to her nor allows her to discharge her duty as a daughter wholeheartedly. 'Should I stay? or Should I go?' (Kieran \& Bella, 2018) Eveline's decision brings disappointment in Frank, hence Eveline's promise to be faithful to Frank is at stake. A moral action, especially a Categorical Imperative should not hurt anyone. Duty or happiness? Eveline was placed in a terrain of dilemma by Joyce. Though Kant condemns hypothetical imperatives and advocates the Categorical imperative on moral grounds, Eveline has become a victim of paralysis due to her moral call, and the Categorical imperative is responsible. Hence Categorical imperative does not ease or relieve Eveline. According to Kant's Categorical Imperative, no human being should be manipulated for someone's own benefit. But her love for Frank indirectly manipulates him to decide to set his home with Eveline. Eveline's choice violates the end-result of Kant's Categorical Imperative as she affected the accomplishment of Frank's desire to live with her. According to Kant, we should be neither manipulated nor manipulate other autonomous agents for our own benefit. Kantianism is quite contradictory if we apply it to the decision of Eveline. Categorical imperatives are all about sticking to the moral rule, where there are never any exceptions which consequently affected two individuals in 'Eveline'.

Joyce's, 'A Painful Case' is framed upon the platonic relationship of a middle-aged married woman and an unmarried man. The story is the last in the adult group, where Joyce employed free indirect style as his narrative technique. Mr. James Duffy is modeled upon Joyce's brother Stanislaus Joyce, whose diary catalyzed Joyce to turn the experiences of his brother into Duffy's. Mr. Duffy, who lives in self-imposed solitude started to fall for Mrs. Emily Sinico as they had common interests. James Duffy lives away from the city in self-imposed solitude. 
Duffy's objectivity is a symptom of his extreme self-consciousness which leads him to fear any kind of emotional engagement with life: "every bond, he said, is a bond to sorrow" (Writework, 2012). James Duffy withdrew himself from the social life leading to emotional sterility. Meeting Mrs.Sinico in the Rotunda, "he was surprised that she seemed so little awkward" (Joyce, 2016, p. 83). They met again in a concert and started enjoying each other's company. As Duffy smelt Mrs. Sinico's invite for romance, he peremptorily repudiates her invite and withdrew himself from their platonic relationship as he felt that Mrs. Sinico would make him fall from his righteousness. Once again, he became solitary by turning down the opportunity of love entering into his life. Four years after their breakup, "A Painful Case", an article in the newspaper drew his attention as it detailed Mrs. Emily Sinico's apparent suicidal death. Mr. Duffy's private, duplicated meals are finally interrupted by the shocking newspaper article that reports Mrs. Sinico's passing away. This disruption makes him recognize that his behaviour cuts him off from society and the love and pleasure of "life's feast" (Joyce's A Painful Case English Literature Essay, n.d.). Duffy's conscience pricked him for the pathetic death of Emily. "He remembered her outburst of that night and interpreted it in a harsher sense than he had ever done" (Joyce, 1996, p. 115). The death of Emily made him blame himself for the first time for his solitude and his so-called righteousness.

Before their breakup, Duffy did not visit her for a week and wrote her to meet after a week. They walked for three hours silently. Was he in a dilemma during their three hours walk? Was she trembling because of disappointment? Joyce shed no light on Duffy's dilemma. "A Painful Case" therefore remains an opaque narrative closet at best. The discourse that constitutes its "closet" is the one that resolutely interprets Duffy's refusal of heterosexual love as volitional in specific registers of ethical culpability coded as egotism, narcissism, solipsism, and coldness (Norris, 2017).

The reason for James Duffy's dilemma is elusive. He is his own protagonist and antagonist. The character, choice, and his image buildup are the consequence of his perception of society, religion, love, etc. Husserl sees intentional consciousness as 'responsible for constituting the appearance of objects as we experience them' (quoted in Lewis \& Staehler, 2011, p. 21). Duffy's artistic interests, like his own imaginative life, are tamed, ordered, classified, and, finally, shelved. Duffy does not act his reasons, but he represents it until he feels guilty or solitary. He fails to identify his soul's joy and realizes his refusal of heterosexual love to be an irreversible blunder immediately after reading the newspaper headline. The news of Mrs. Sinico's death "roused him out of his deadly sleep" (Coleman, 1991) and seeded the feeling of guilt within him.

Joyce has pitched the domination of id, ego, and superego in Duffy to give a Freudian touch to his short story. Beggars never touched or moved his heart as he never gave alms to them. His uncaring and unempathetic nature is due to the suppression of the superego. But his superego erupted as guiltiness because of the tragic loss of another psyche. He had been transforming unknowingly emotional as he started to share with her and allowed her to dominate his intimate thoughts. "This union exalted him, wore away the rough edges of his character, emotionalized his mental life" (Joyce, 1999). Freudian Id started to illumine and revive him emotionally to rescue him from his saturnine domination. But his revivification did not last long due to ego's domination once again as Duffy wanted to turn to his righteous path without falling prey to adultery. His imbalanced ego activated him to not relinquish his own fettered predominant self-paralysis. On the contrary, Emily's Id, guided her to be expressive, sensitive and to release her from the entrapped abysmal wedded life. The portrayal of characters in 'A Painful Case', does make us wonder if Joyce created the characters Duffy and Emily to showcase his knowledge of Freudian tripartite division of the human psyche.

Freud's pleasure principle," coincides succinctly with the function of a subcortical (and therefore non-rational) region of the human brain called the amygdala which has traditionally been associated with fear in response to environmental danger ... and in the case of pleasure the amygdala functions as a memory storage device, associating neutral stimuli with 'motivationally relevant' stimuli such as food, sex, or danger," thereby building up stimulus-response bonds based on reward as well as punishment (Cohen, 2020). In the case of Eveline and Duffy amygdala played a great role in generating fear. The amygdala is considered to be a part of the limbic system within the brain and is likely to be responsible for processing emotions such as pleasure or fear. 'To fight or flight response' is triggered by the amygdala. Duffy's amygdala always chose flight response instead of choosing to fight at times: Duffy renounced the call for his religious vocation, imposed self-isolation, rejected the invitation of love and romance. But in 'Eveline', instead of flying away from the drunken father Eveline's amygdala made her choose to fight and suffer.

Several studies have consistently linked moral judgment with the cortical region of the brain known as the ventromedial prefrontal cortex (VMPFC). This area of the brain has reciprocal neural connections with the amygdala and is intimately bound up with emotional control. Hence, it is poised to serve as a source of "conflict" with the amygdala "id", Clinical studies also point to a major involvement of the VMPFC in "guilt-related 
affective processing," thereby further marking this brain region out as a likely substrate for the superego (Cohen, 2020). Duffy renounced the call for his religious vocation, rejected the invitation of love and romance, and imposed self-isolation: all these projects him as a person with an imbalanced psyche. In Freudian terms, ego, id, and superego took their turn to dominate Duffy, whereas only Id dominated Mrs. Sinico.

The memories of the cascade of events after meeting Mrs.Sinico started occupying his brain and stimulated his neocortex known as the thinking brain. As a result, finally, he has come to accept that his former perceptions of himself and his world were misguided by a harsh and unforgiving intellect and, as a result, he suffers a full-scale collapse: "He began to doubt the reality of what memory told him ..., he felt that he was alone" (Joyce, 1999, p. 117). His rejection ended in ignominy, a suicidal death. Mrs. Sinico's death unquestionably drove him to the edge of neurosis.

Duffy's decision to turndown Emily's love may not be conclusive as he feels guilty by the end of the story. He must have had internal dilemmas during their one-week gap before the last meeting. Duffy might have justified himself about his platonic love, but the moment Emily's hand touched Duffy's, his Categorical Imperative forced him to end up Emily's love and affection for him. If we look through the lens of Immanuel Kant's approach to the moral conflict, being in love with a married woman is a violation of the moral code of conduct. Mr. Duffy mistakenly sees this gentlewoman as an unfortunate detour from his arid and self-assured path and so he ends the affair (Coleman, 1991). Duffy's decision is driven by the Categorical imperative, through which he places himself as a person of morality. Renouncement of his priesthood, being cold to the beggars and staying aloof, and continuing his mundane life are the ends of his hypothetical imperatives. His hypothetical imperatives affected the psyche of none, whereas his Categorical imperative leads to Emily's psychosis. Mr. Sinico's rejection and Duffy's further rejection caused rooted psychosis within Emily. Duffy and Emily's union would have ended the abysmal wedded life of Emily and the mundane solitary life of Duffy but being Categorical imperative as Dubliners' choice their lives turned to be pathetic.

Both in Eveline and James Duffy, Eros has been absent. The dominance of Thanatos in both the characters blindfolded them to see the source of joy and long-lasting happiness. James Joyce blamed Dubliners for choosing Categorical imperatives and enhancing self-imposed sterility. The imbalance of Id, Ego, and Superego cost the life of Emily and the paralysis of Eveline. In essence, James Duffy moved from his state of unfeeling solitude into an awareness of his own and others' humanity but, coming as it has through the destruction of another person, it has banished him from life and left him wasted (Coleman, 1991). Imperatives can be self-destructive at times and can lead to an imbalance of the human psyche. Freud shared with Kant a vision of human beings as committed to a moral venture. Freud as a modernist conceived psychoanalysis and fulfilled the quest of moral responsibility (Tauber, 2009). Through the cross-pollination of Kantian imperatives and Freudian psyche, Joyce as a modernist chiseled his characters and attempted to teach Dubliners reason and self-inquiry. In an instrumental sense, reason becomes the tool by which humans become moral in each context-Kantian and Freudian (Tauber, 2009). Joyce believed that self-discovery would lead to personal insight and understanding constitute the right of freedom humans should enjoy by exercising their choice. 'To know thyself' is the priority of Joyce, which he expected the tethered Dubliners to exercise to live life to the fullest.

\section{Acknowledgments}

The author would like to thank Arab Open University, Saudi Arabia for supporting this research paper.

\section{References}

ArticlesPsychology. (2017, October 27). How the Brain Reacts to Difficult Moral Issues. Neuroscience News. Retrieved from https://neurosciencenews.com/moral-issues-neuroscience-7824/

Brook, A. (2003). Kant and Freud. In M. C. Chung \& C. Feltham (Eds.), Psychoanalytic Knowledge. London: Palgrave Macmillan. https://doi.org/10.1057/9780230001152_2

Cohen, E. (2020, March 20). Freud's Brain | Psychology Today. Sussex Publishers. Retrieved from https://www.psychologytoday.com/us/blog/what-would-aristotle-do/202003/freuds-brain

Coleman, G. B. (1991). Imagination, Illusion, and Vision in James Joyce's Dubliners. Macphere, Mcmaster University, Ontario. Retrieved from https://macsphere.mcmaster.ca/bitstream/11375/12031/1/fulltext.pdf

Conrad, B. (2018, November). The Role of Dopamine as a Neurotransmitter in the Human Brain. Retrieved from

https://www.enzolifesciences.com/science-center/technotes/2018/november/the-role-of-dopamine-as-a-neur otransmitter-in-the-human-brain/ 
Dubliners - Maturity (“A Painful Case”) - WriteWork. (2012). Write Work. Retrieved from https://www.writework.com/book-guides/dubliners-james-joyce/maturity-painful-case

Ellmann, R. (2003). Selected Letters of James Joyce (Main Ed.). Faber and Faber, London.

Ingersoll, E. G. (1993). The stigma of femininity in James Joyce's "Eveline" and "The Boarding House." Studies in Short Fiction, 30(4), 501. Retrieved from https://ink.gale.com/apps/doc/A14762709/AONE?u=anon bb173d8b\&sid=googleScholar\&xid=7c55924e

Joyce, J. (1999). Dubliners (Wordsworth Classics) (Revised ed.). Wordsworth Editions Ltd.

Joyce, J. (2016). James Joyce The Dover Reader (Dover Thrift ed., 1st ed.). Dover Publications, New York.

Joyce, J., Scholes, R., \& Litz, W. A. (1996). Dubliners: Text and Criticism (Critical Library, Viking) (Revised ed., Reprint, Subsequent ed.). Penguin Books, New York.

Joyce's A Painful Case English Literature Essay. (n.d.). Retrieved April 5, 2021, from https://www.uniassignment.com/essay-samples/english-literature/joyces-a-painful-case-english-literature-es say.php\#: :text=In $\% 20 \% 22 \mathrm{~A} \% 20$ Painful $\% 20$ Case $\% 20 \% 22$ the,taught $\% 20$ himself $\% 20$ simply $\% 20$ to $\% 20$ see .\&text $=\mathrm{As} \% 20$ one $\% 20$ person $\% 20$ notes $\% 3 \mathrm{~A} \% 20 \% 22 \mathrm{It}$,Duffy\%20himself\%20rather\%20than $\% 20 \mathrm{Mrs}$

Kieran, M. K., \& Bella Vista Preparatory School. (2018, November). Eveline, Should I Stay or Should I Go? Course Hero. Retrieved from https://www.coursehero.com/file/48256827/Eveline-Should-I-Stay-or-Should-I-Go/

Kuparadze, G. (2012). Intertextual and Stylistic in James Joyce's Eveline (pp. 107-114). Collected Papers ofInternational Conference English Department of Ivane Javakhishvili Tbilisi State University and James Joyce Association of Georgia Tbilisi.

Lewis, M., \& Staehler, T. (2011). Phenomenology: An Introduction (1st ed.). Continuum, London. https://doi.org/10.5040/9781350251861

Mambrol, N. (2020, December 27). Analysis of James Joyce's Dubliners. Literary Theory and Criticism. Retrieved from https://literariness.org/2020/12/27/analysis-of-james-joyces-dubliners/

Miller, F. P., Vandome, A. F., \& McBrewster, J. (2009). Id, Ego, and Super-Ego. Van Haren Publishing.

Norris, M. (2017). The Self-Disputing Text of Dubliners. OpenEdition Books. Retrieved February 9, 2021, from https://books.openedition.org/pufr/4521?lang=en

Sagan, E. (1988). Freud, Women, and Morality: The Psychology of Good and Evil (1st ed.). Basic Books.

Tauber, A. I. (2009). Freud's dreams of reason: The Kantian structure of psychoanalysis. History of the Human Sciences, 22(4), 1-29. https://doi.org/10.1177/0952695109340492

\section{Copyrights}

Copyright for this article is retained by the author, with first publication rights granted to the journal.

This is an open-access article distributed under the terms and conditions of the Creative Commons Attribution license (http://creativecommons.org/licenses/by/4.0/). 